ZDRAVKO TOŠ, Ph.D.

E-mail: zdravko.tos@fpz.hr

TOMISLAV JOSIP MLINARIĆ, Ph.D.

E-mail: mlinaric@fpz.hr

HRVOJE HARAMINA, Ph.D.

E-mail: hrvoje.haramina@fpz.hr

University of Zagreb,

Faculty of Transport and Traffic Sciences

Vukelićeva 4, 10000 Zagreb, Croatia
Traffic Management Original Scientific Paper Accepted: Mar. 24, 2011 Approved: Nov. 15, 2011

\title{
MANAGING RAIL TRAFFIC ON COMMUTER LINES BASED ON DYNAMIC TIMETABLE APPLICATION
}

\begin{abstract}
The increase of demand for transport service in rail commuter traffic stipulates higher ratio of consumed infrastructure capacity. In this method of traffic flow even minor deviations from the planned timetable can have negative influence on its stability, and this can result in major reduction of the quality of transport service. This research has defined the commuter rail traffic management system model with the application of real-time timetable rescheduling. It understands the application of the decision support system during the procedure of adjusting the timetable to the real condition in traffic in the form of genetic algorithm defined on the basis of the valid rules for the train and traffic control. Besides, this model in all the commuter trains understands the existence of the driver advisory system which is based on the algorithm for determination of the most favourable running regime with the aim of saving in energy consumption. The paper proves that by applying the proposed model the commuter rail traffic can be improved regarding the increase of the timetable stability and energy-efficient train operation.
\end{abstract}

\section{KEY WORDS}

rail traffic management, genetic algorithm, energy efficient timetabling and train operation

\section{INTRODUCTION}

Rail traffic on commuter lines always refers to the areas of big urban centres. For the travelling within these centres as a rule the directions, relations and time are known because their basic characteristic are the daily migrations of a large number of passengers. Therefore, the organization of commuter traffic needs to be set in such a way as to satisfy the needs of these passengers by the frequency of trains and the offered means / capacities.

The increase of demand for transport service in rail commuter traffic stipulates higher ratio of consumed infrastructure capacity. The basic precondition to meet this increased demand is in the first place the achievement of satisfactory level of availability of infrastructure capacity. This requires the need for detailed knowledge of the utility condition of the track sections [1]. The more so since in this method of traffic operation even minor deviations from the planned timetable negatively influence its stability, and this may result even in significant reduction in the quality of transport service.

On the other hand, there is the issue of timetable stability from the aspect of organization and regulation of rail passenger carriage in commuter traffic. In this sense it is necessary to develop a high-quality model of predictive management system, which might additionally improve the timetable stability and the quality of transport service in rail commuter traffic. This would at the same time enable raising of the quality of exploitation and maintenance of traction vehicles which are used in this technological process [2], as well as the saving of energy for commuter trains operation.

In this method of traffic flow, in spite of the application of centralized managing method, due to the complexity of the problem regarding determination of the optimal traffic operation, it is necessary to reduce the workload of the dispatcher in traffic regulation. This can be achieved by introducing expert systems which serve the dispatcher as support in decision-making in the traffic control process $[3,4,5]$.

\section{DESCRIPTION OF RAIL TRAFFIC MANAGEMENT MODEL WITH DYNAMIC TIMETABLE APPLICATION}

The model understands centralized managing of rail commuter traffic, with the dispatcher who is at the managing centre having the task of making decisions on the method of train traffic regulation in the defined management area. At every stop there is stationary 


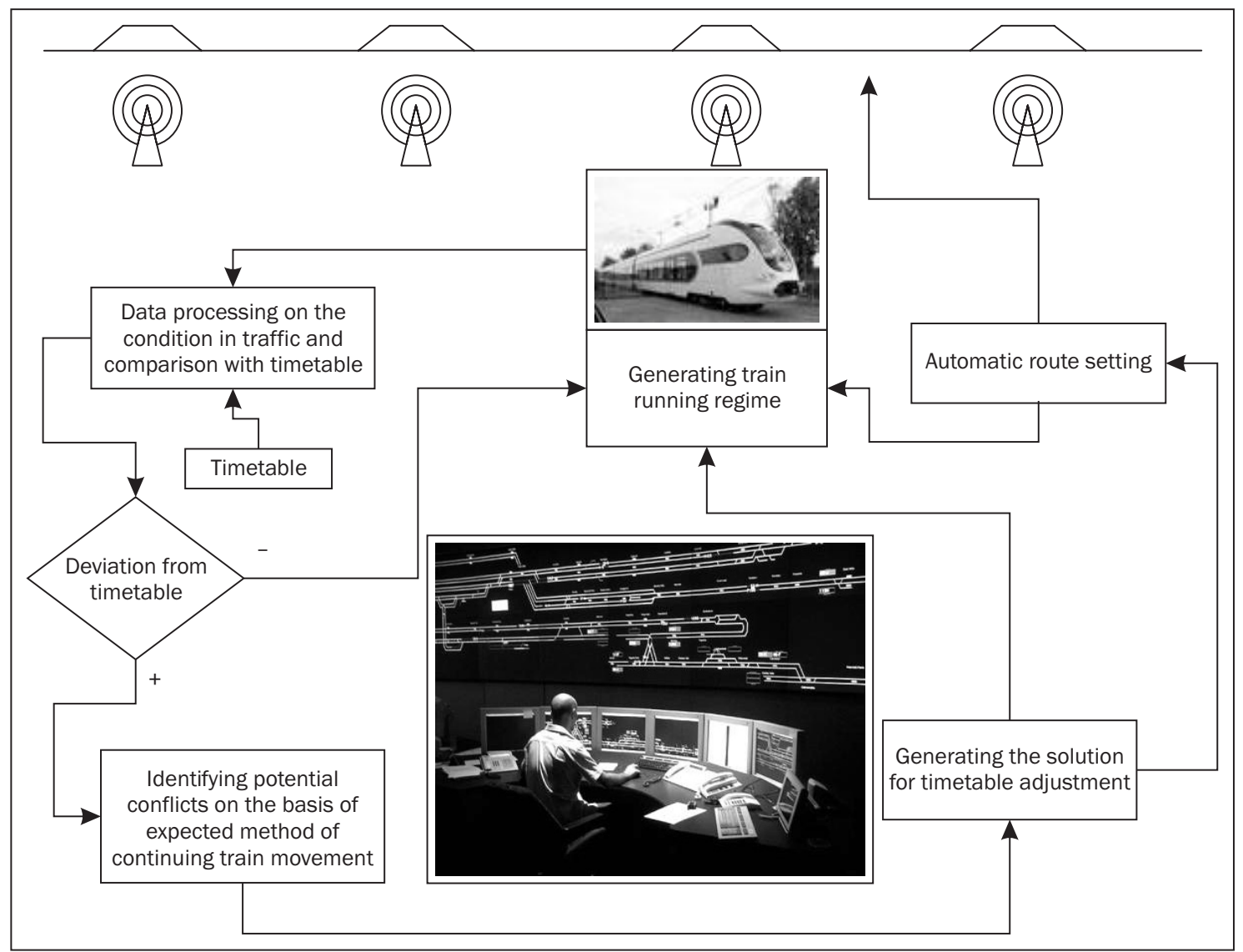

Figure 1 - Conceptual presentation of the model of predictive management system

equipment which allows two-way information transfer between the managing centre and commuter trains by digital radio. The trains send towards the managing centre the data on time of their arrival and departure from the stop, and they receive from the managing centre the data on changes in the timetable.

In this way the managing centre and all the commuter trains that participate in the traffic process exchange data that are important for the traffic management process. The model also understands the action of the system for automatic setting of routes for trains with the selection of routes according to the identification of the train number (see Figure 1).

As part of this model, during the process of centralized traffic management the dispatcher uses the system as assistance in decision-making in the form of the expert system that proposes solutions for the adjustment of the timetable to the real condition in traffic. The action of this expert system is based on the work of the genetic algorithm defined on the basis of the valid rules for the regulation of rail traffic and train guidance as well as input data that refer to the planned timetable and its execution in real time.

This model also in all commuter trains means the existence of the expert system that serves for determining of the best regime of their movement with the aim of energy saving necessary for their propulsion.
By arriving to the stop the trains use digital radio transmission to send data on the times of their arrivals and departures toward the managing centre. These data are processed at the managing centre and their comparison with the valid timetable shows possible deviations in its realization, Figure 1 . In case of such deviations, the expert system for the adjustment of the timetable to the actual condition in traffic acts in such a way as to use the predictions of the continuation of movement of all trains within a shorter future period (e.g. 1 to 10 minutes), which depends on the characteristics of the traffic process, to determine all the potential conflicts that may occur between the predicted train routes in the valid timetable (see Figure 2).

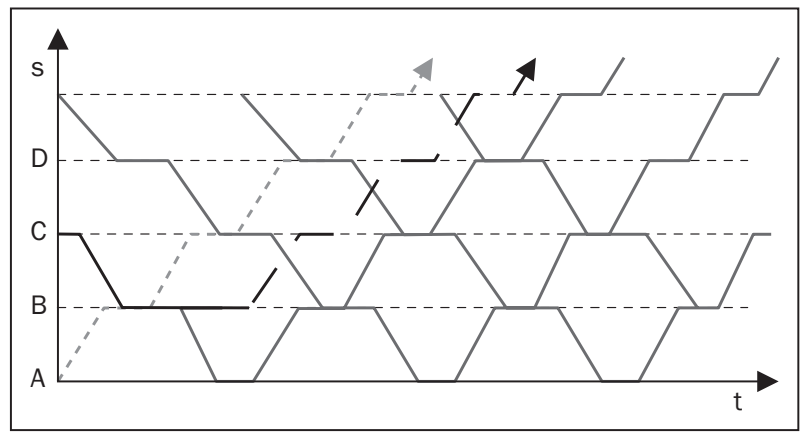

Figure 2 - Identifying potential conflicts in the timetable based on train movement prediction 
Based on the predicted potential conflicts, the expert system based on the genetic algorithm adjusted to solve these types of problems, searches the space for possible solutions with the aim of finding a satisfactory solution for the adjustment of the timetable to the new situation in traffic.

The satisfactory solution should in the shortest time possible annul the influence of the deviation and enable traffic operation according to the planned timetable with the reduction of the total delay time of the commuter trains.

After the completed process of adjustment the dispatcher should decide about the acceptance of the offered solution. In case that the dispatcher accepts the offered solution proposal the procedure of its implementation into the traffic process is started. The system for automatic train routing acts in accordance with the accepted timetable solutions, and using the digital radio transmission system it is broadcast to all the commuter trains.

Based on the planned times of train arrivals and departures, that is, from their travel times and times of stay at the stops, the expert system installed in every commuter train determines their running regimes in order to realize the objectives set within the procedure of timetable adjustment, with minimal driving energy consumption. Here, the time period between two train departures from the stop is divided into the time that is necessary for the stay of train at the stop and the available running time. As part of this division good predicting of the necessary time of train stay at the stop plays an important role so that by selecting the optimal train running regime, the remaining time available for its running would be efficiently used regarding the saving of energy.

\section{GENETIC ALGORITHM FOR TIMETABLE ADJUSTMENT TO REAL CONDITION IN TRAFFIC}

Modern rail traffic management systems regarding the reduction of the dispatcher's workload understand the application of the support system for the dispatcher in decision-making during the traffic regulation process. Their work is based on the specially adapted algorithms for real-time timetable rescheduling with the aim of its adjustment to real traffic conditions. It is, namely, known that the issue of timetable adjustment to the real condition in traffic as a combinatory problem belongs to the group of NP-difficult problems [6].

The known algorithms for solving such problems are in the best case of exponential complexity, i.e. execution time is of exponential growth in relation to the number of variables. Regarding the characteristics of the technological process of passenger carriage the mentioned problem need not necessarily be solved exactly, but rather it should be solved approximately e.g. by the application of the heuristic methods. Therefore, the model of the anticipated traffic management in order to adjust the timetable to the real condition in traffic understands the action of expert system that is based on the application of the genetic algorithm. The genetic algorithm for real-time timetable rescheduling has been developed by usage of Genetic Algorithm Tool of MatLab software package.

In case of deviation in the timetable in the form of delay of certain trains, and taking into consideration that there is the possibility of occurrence of knock-on delays i.e. influence of the existing delays on the regular running of other trains on the track, the timetable adjustment procedure is performed, in which the genetic algorithm based on the potential train movement regimes and the set limits regarding the interdependence of single routes in the timetable, determines for every train new times of departures and arrivals to the planned stops. The objective of this procedure is to eliminate, in case of train delay, the influence of the resulting deviations in the timetable on their further realization by changing the train running regime, that is, by adjusting their timetables and the time of stay at the stops with minimal modification of the planned timetable. The restrictions of the genetic algorithm are set on the basis of the data about the given clockfaced timetable of the commuter trains. The function of objective is defined by the sum of train arrival times to the destination stations in which they terminate their trip, according to the expression:

$$
\begin{aligned}
F(x) & =x_{4}+x_{18}+x_{28}+x_{48}+x_{55}+x_{64}+ \\
& +x_{77}+x_{83}+x_{84} \rightarrow \min
\end{aligned}
$$

where $x_{i j}$ denotes the time of train arrival to the station in which it terminates its ride as part of one cycle.

The lower value of the function of objective denotes also the minor value of the total deviation in relation to the initial one, i.e. the planned timetable. The initial timetable means a single cycle of the clock-faced timetable of the commuter trains in the duration of 120 minutes, (see Figure 3).

For the sake of model verification, a case of deviation from the planned timetable has been simulated, in which train 14 unexpectedly extends its stay at station $D$ for 3 minutes and its departure is in $47^{\text {th }}$ minute, and train 15 departs regularly from the stop $\mathrm{F}$.

$T_{p D}^{14}=47$

$x_{1}=47$

Aeq[1 0000000000$]$; beq[47]

$T_{p F}^{15}=48 ;$

$x_{2}=48$

Aeq[0 10000000 0]; beq[48]

In the presented expressions the mathematical equations are adjusted to the work of the genetic algorithm by their conversion into a binary series of 8 


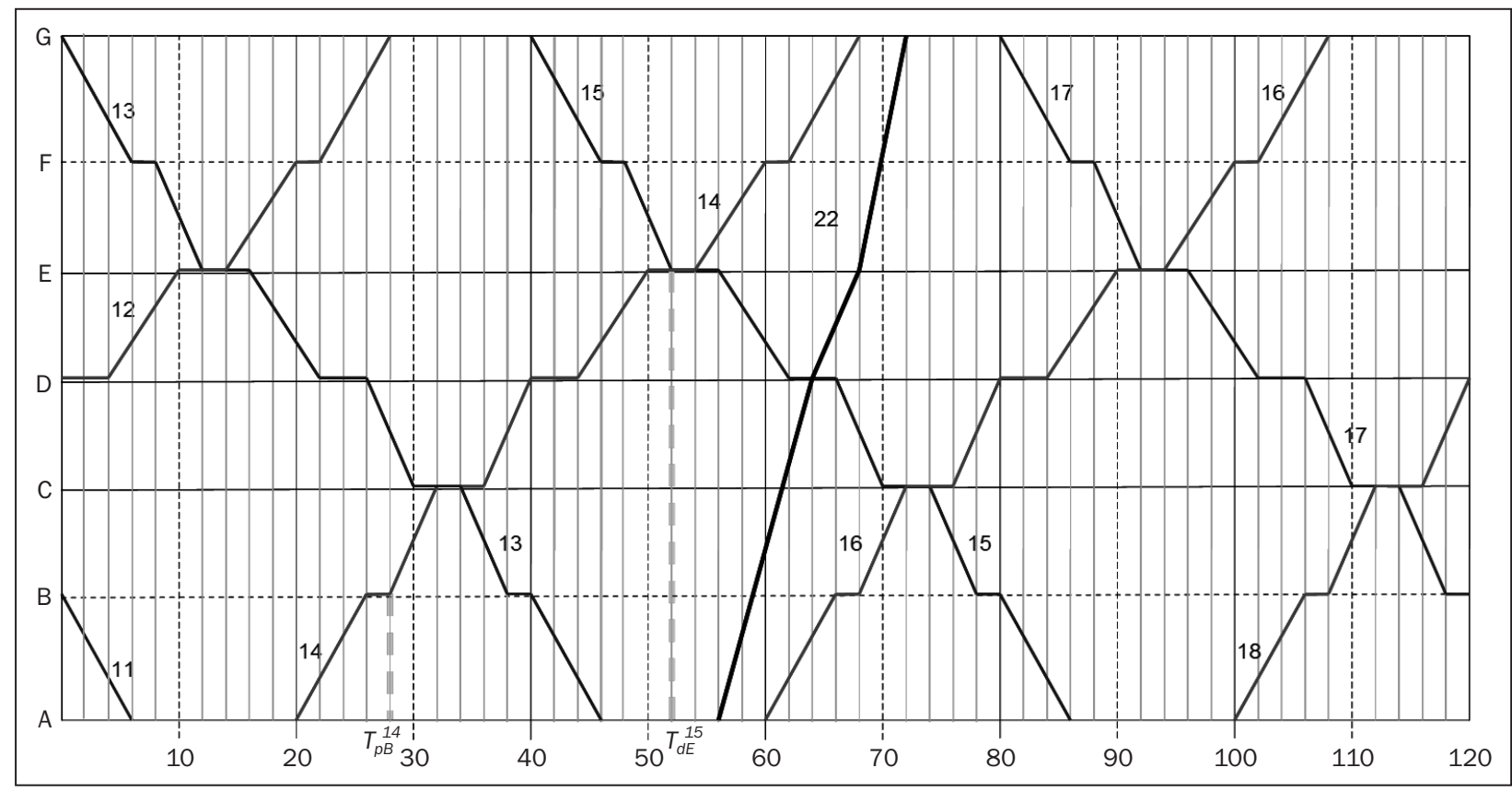

Figure 3 - Clock-faced timetable cycle of commuter trains

elements that represent eight different symbols of the times of train departure and arrival to the stop. Each binary series is assigned a certain value of time of departure, that is, arrival of a certain train to a certain stop.

Here, because of the adjustment of work in the software package Matlab, instead of the symbol for time of departure, i.e. time of arrival of the train to the stop, on the left side of the equation there is the binary series marked by Aeq (Eng. Mathematical Equation). On the right side there is the concrete value of the departure, i.e. arrival of the train to the stop with beq. Besides, in some expressions the symbols Ainq and binq are used and they refer to the mathematical non-equations.

Taking into consideration that there is a possibility of impact of the delays on the regular driving of other trains on the line, the timetable adjustment is performed, where the genetic algorithm based on the potential train movement regimes and the set restrictions regarding the interdependence of single routes in the timetable, determines for each train new departure and arrival times for the planned stops.

The aim of this procedure is, in case of train delays, to eliminate the impact of the deviations from the planned timetable on further performance, by changing the train running regime, i.e. by adjusting their timetables and the times of stays at the stops [7].

Regarding the in-advance defined train running regimes, (see Figure 6), the restrictions related to timetables of trains 14 and 15 have been defined, with restrictions for the travel time of train 14 on the relation between stations $\mathrm{D}$ and $\mathrm{E}$ being given by expressions: $T_{d E}^{14} \geq T_{p D}^{14}+4.5$ that is $T_{p D}^{14}-T_{d E}^{14} \leq-4.5$
It follows that:

$x_{1}-x_{3} \leq-4.5$

Aineq[1 0 -1 00000 0]; bineq[-4.5]

$T_{d E}^{14} \leq T_{p D}^{14}+9$; that is $T_{d E}^{14}-T_{p D}^{14} \leq 9$;

It follows that:

$x_{3}-x_{1} \leq 9$

Aineq[-1 011000000 ; bineq[9]

and time limit of arrival of train 14 to station $\mathrm{E}$ regarding the planned timetable is given by expression:

$T_{d E}^{14} \geq 50$; that is $-T_{d E}^{14} \leq-50$;

It follows that:

$-x_{3} \leq-50$

Aineq[0 0 -1 000000 0]; bineq[-50]

For train 15 the restrictions are given by the following expressions:

$T_{d E}^{15} \geq T_{p F}^{15}+3 ;$ that is $T_{p F}^{15}-T_{d E}^{15} \leq-3$

It follows that:

$x_{2}-x_{4} \leq-3$

Aineq[0 10 -1 000 0 0]; bineq[-3]

$T_{d E}^{15} \leq T_{p F}^{15}+7$; that is $T_{d E}^{15}-T_{p F}^{15} \leq 7$

It follows:

$x_{4}-x_{2} \leq 7$

Aineq[0 -1 0100000$]$; bineq[7]

$T_{d E}^{15} \geq 52$; that is $-T_{d E}^{15} \leq-52$

It follows that:

$-x_{4} \leq-52$

Aineq[0 00 -1 0000 0]; bineq[-52]

The value of the station interval of non-simultaneous arrival of trains predicted for the needs of com- 
muter train crossings at interstations is determined on the basis of the assumption of the travel time of the commuter trains from the point of regulated visibility distance of the distant signal to the point of the train halt at the station and it is $\mathbf{1 . 5}$ minute, and the difference in the departure time of the first and second train which are crossing in the station is 0.5 minutes where the limits are given by the following expressions:

$T_{d E}^{15} \geq T_{d E}^{14}+1.5 ;$ that is $T_{d E}^{14}-T_{d E}^{15} \leq-1.5$

It follows that:

$x_{3}-x_{4} \leq-1.5$

Aineq[0 01 -1 00000 0]; bineq[-1.5]

$T_{p E}^{14} \geq T_{d E}^{15}+0.5 ;$ that is $T_{d E}^{15}-T_{p E}^{14} \leq-0.5$

It follows that:

$x_{4}-x_{5} \leq 0.5$

Aineq[0 $0001-100$ 0]; bineq[-0.5]

$T_{p E}^{15} \geq T_{p E}^{14}+0.5 ;$ that is $T_{p E}^{14}-T_{p E}^{15} \leq-0.5$

It follows that:

$x_{5}-x_{6} \leq 7$

Aineq[0 00001 -1 00 0]; bineq[-0.5]

The values of times necessary for the commuter trains to stay at certain stops have been determined by the action of the fuzzy inference system (FIS) [8]. The output values, namely, of the fuzzy logic process represent the operation parameters of the genetic algorithm regarding the limitations of the time the train stays at the stops, which is given by the expressions: $T_{p E}^{14} \geq T_{d E}^{14}+F I S$ that is $T_{d E}^{14}-t_{p E}^{14} \leq F I S$

It follows that: $x_{3}-x_{5} \leq-3.5$

Aineq[0 010 -1 000 0]; bineq[-3.5]

$T_{p E}^{14}-T_{d E}^{14} \leq 4$

It follows that:

$x_{5}-x_{3} \leq 4$

Aineq[0 0 -1 0101000 0]; bineq[4]

$T_{p E}^{14} \geq 54$; that is $-T_{p E}^{14} \leq-54$

It follows that:

$-x_{5} \leq-54$

Aineq[0 000 -1 000 0]; bineq[-54]

$T_{p E}^{15} \geq T_{d E}^{15}+$ FIS (2.5); that is $T_{d E}^{15}-T_{p E}^{15} \leq$ FIS

It follows that:

$x_{4}-x_{6} \leq-2.5$

Aineq[0 0010 -1 0 0]; bineq[-2.5]

$T_{p E}^{15}-T_{d E}^{15} \leq 4$

It follows that:

$x_{6}-x_{4} \leq 4$

Aineq[0 00 -1 010 0]; bineq[4]

$T_{p E}^{15} \geq 56$; that is $-T_{p E}^{15} \leq-56$

It follows that:

$x_{6} \leq-56$

Aineq[0 $0000-100]$; bineq[-56]

The graphic interface as part of the Genetic Algorithm Tool in software package MatLab [9] was used to perform the simulation of the timetable adjustment to the real condition in traffic, (see Figure 4).

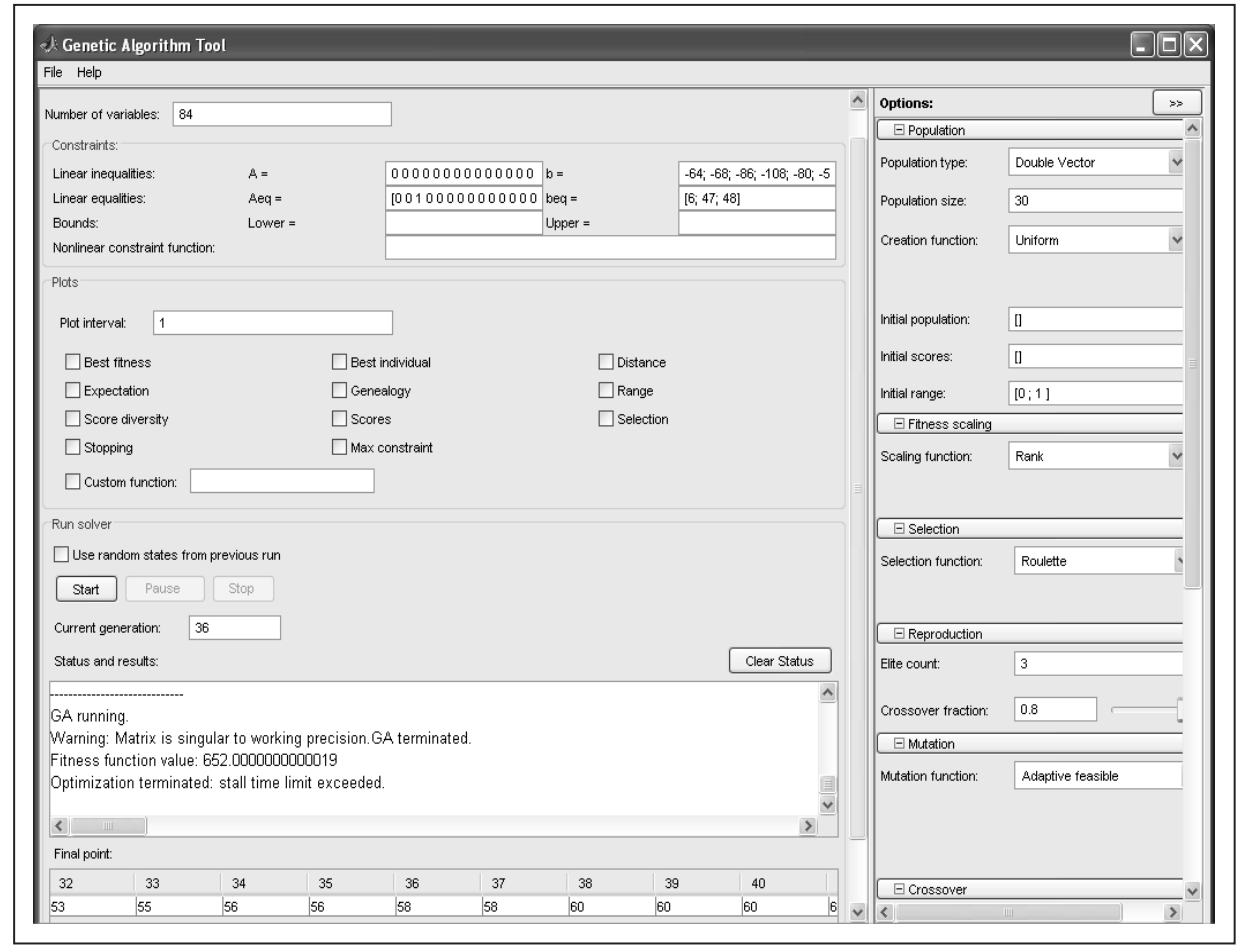

Figure 4 - Interface for work with the genetic algorithm in Matlab software 


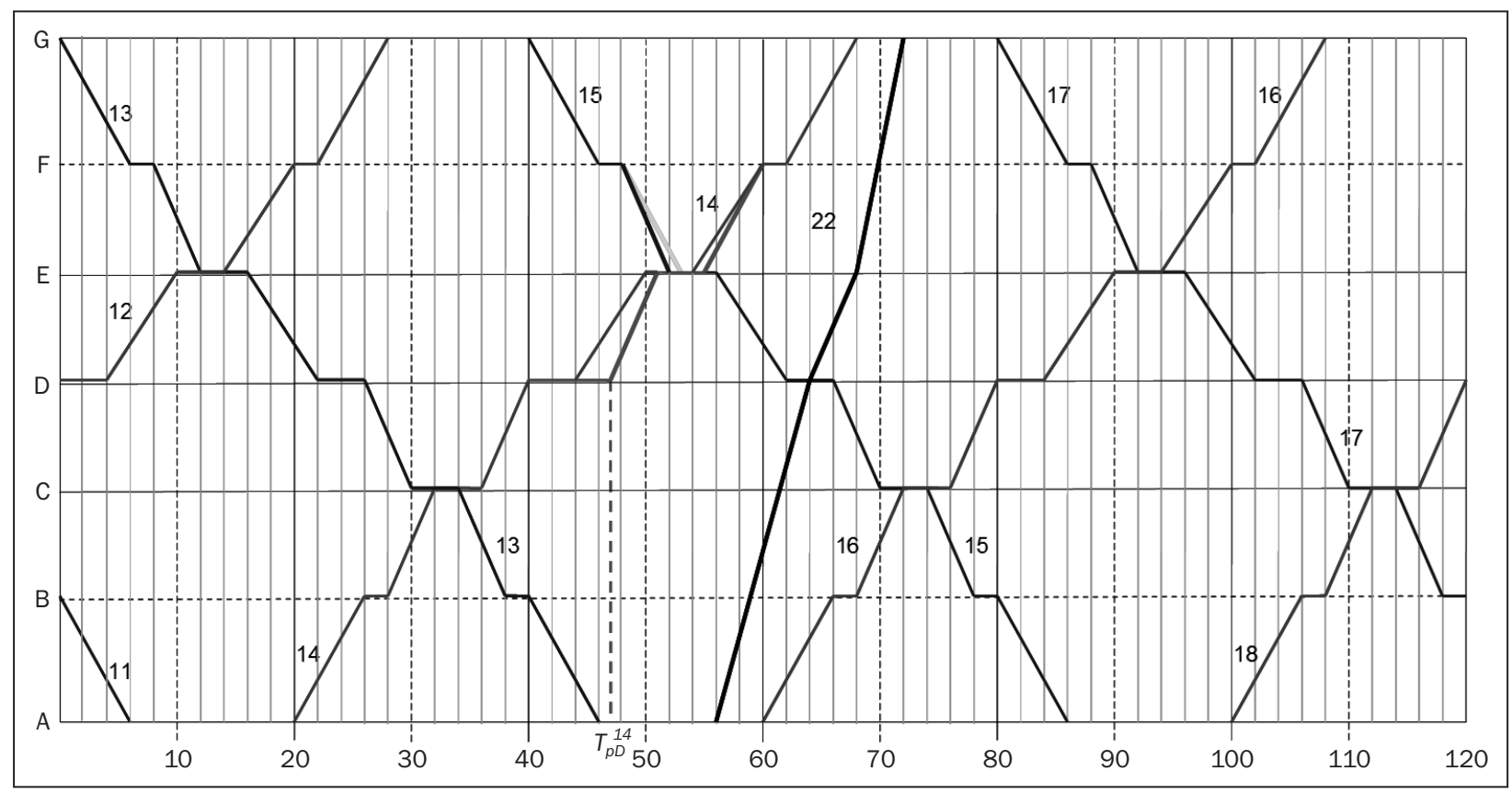

Figure 5 - Results of the timetable adjustment to real traffic condition

The results of the simulation show that if train 14 has an unexpected delay in departure from stop $D$ of three minutes, the support system will provide the dispatcher with a new solution for the timetable adjustment, which is in the form of a timetable graph presented in (Figure 5).

\section{SYSTEM FOR DETERMINING THE TRAIN RUNNING REGIME}

It should be emphasised that in timetable adjustment the aim is to avoid major modifications of the planned timetable, that is, such solutions should be found that will annul in the shortest time possible the impact of the delays and allow further traffic flows according to the planned timetable. This can be achieved by adequate adjustment of the timetables of trains included in the optimisation procedure with the change of their running regimes.

Determining of the optimal train running regime is performed in order to adjust the method of their movement with the aim of implementing the accepted solution for the regulation of rail traffic with the possibility of increasing the rail traffic efficiency. The objective is, namely, to select the optimal train running regime that would realize the given travel time. Thus, for example, by selecting the better running regime that for instance means shorter travel time in relation to the one planned by the timetable, the train may compensate its possible delay in departure from the stop.

In case when there are several different running regimes that make it possible to achieve this goal, the one is selected which is optimal regarding energy saving. Here as well, for each train a certain number of potential driving regimes may be determined in advance for each interstation space one of which is the initial one and the travel time calculated for this driving regime is built into the planned timetable. Other driving regimes allow shorter, i.e. longer travel times in relation to the ride according to the initial movement regime. In order to avoid major reduction of the utilisation of the rail line capacity, shorter travel times should not deviate too much from the one planned in the initial timetable. On the other hand, the aim of planning somewhat longer travel times in relation to those determined according to the traction calculations as the shortest, is to allow compensation of possible train delays and lower energy consumption.

Train running regimes that result in longer travel times in relation to the initial ones, are suitable in case when out of traffic reasons a train cannot enter the station area within the planned time, and if driving according to the initial running regime it should stop in front of the entry signal. Such regimes understand higher share of coasting within the train running regime, which results in longer travel time, but also in the reduction of energy consumption [10].

As part of the model of the predictive management system the new method of determining the optimal train running regime was applied. This means previous determination of a certain number of possible commuter train running regimes, where during the traffic process realisation, and based on the real condition in traffic, every train selects its best running regime. Thus, for instance, if a certain train is delayed in departure from a certain stop, depending on the delay value, one of the in-advance planned alternative running regimes is implemented. Every such driving regime results in 
certain train travel time on the relation between two stops. By selecting the best driving regime it is possible to realize travel times set by the accepted solution for the adjustment of the timetable to the real condition in traffic, where this method imposes a certain restriction in the operation of the genetic algorithm. This restriction refers to the fact that the genetic algorithm can define new times of arrivals to stations and stops taking into consideration the limited number of the already inadvance defined running regimes.

In case that several running regimes of a crossing train correspond to the requirements for the timetable adjustment to the real condition in traffic, e.g. when the opposite-running train has a certain greater delay, but not such that their meeting point should be changed, then energy-most-efficient running regime is selected for the crossing train. In that case this would be the running regime that contains the highest share of coasting in relation to other potential regimes, which also means the longest travel time.

In the timetable defined for the needs of this model, since the model means straight railway line free of gradients and curves, it has been determined that the ride of every train can be realised by the implementation of one of eight available running regimes. The trains in this case, depending on the share of coasting within individual regime can realise travel times in the duration of $3,4.5,4,5,6,7,8$ and 9 minutes. The given running regimes of commuter trains are graphically presented in (Figure 6).

When the trains receive the new solution of the timetable, the best of the in-advance defined running regimes is selected with the aim of carrying out the planned timetables. The procedure of selecting the most favourable running regime is based on the division of timetables adjusted to the given running regimes, (see Figure 7).

\section{CONCLUSION}

The results of the simulation of the genetic algorithm for timetable adjustment to the new condition in traffic clearly show that by implementing the proposed model the commuter rail traffic can be improved. The algorithm, namely, in case of deviations in the realization of the timetable provides satisfactory solutions that annul the impact of this deviation on the timetable stability and in the shortest time possible allow the continuation of the traffic flow according to the planned timetable. The obtained solutions for the timetable adjustment mean the implementation of the train movement regime with higher share of coasting which allows also certain savings in the energy powering the commuter trains.

There is higher probability for the deviation from the pre-planned timetable during its realisation at times of

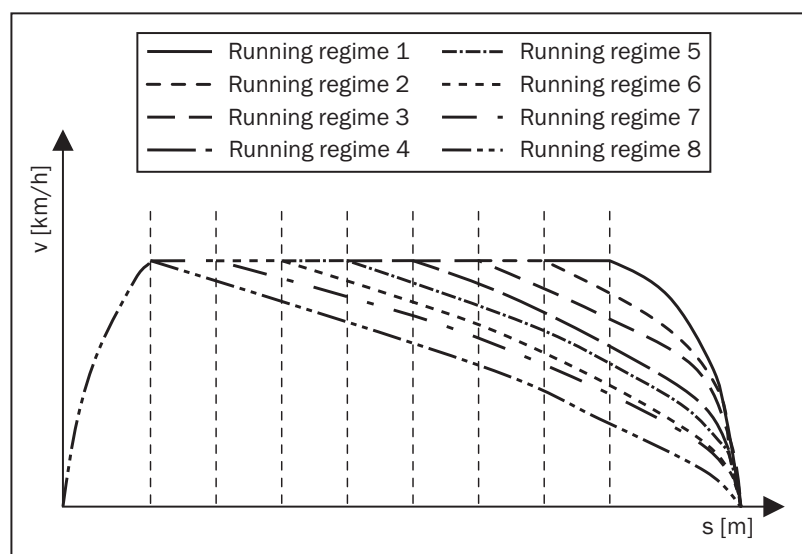

Figure 6 - Given running regimes of commuter trains

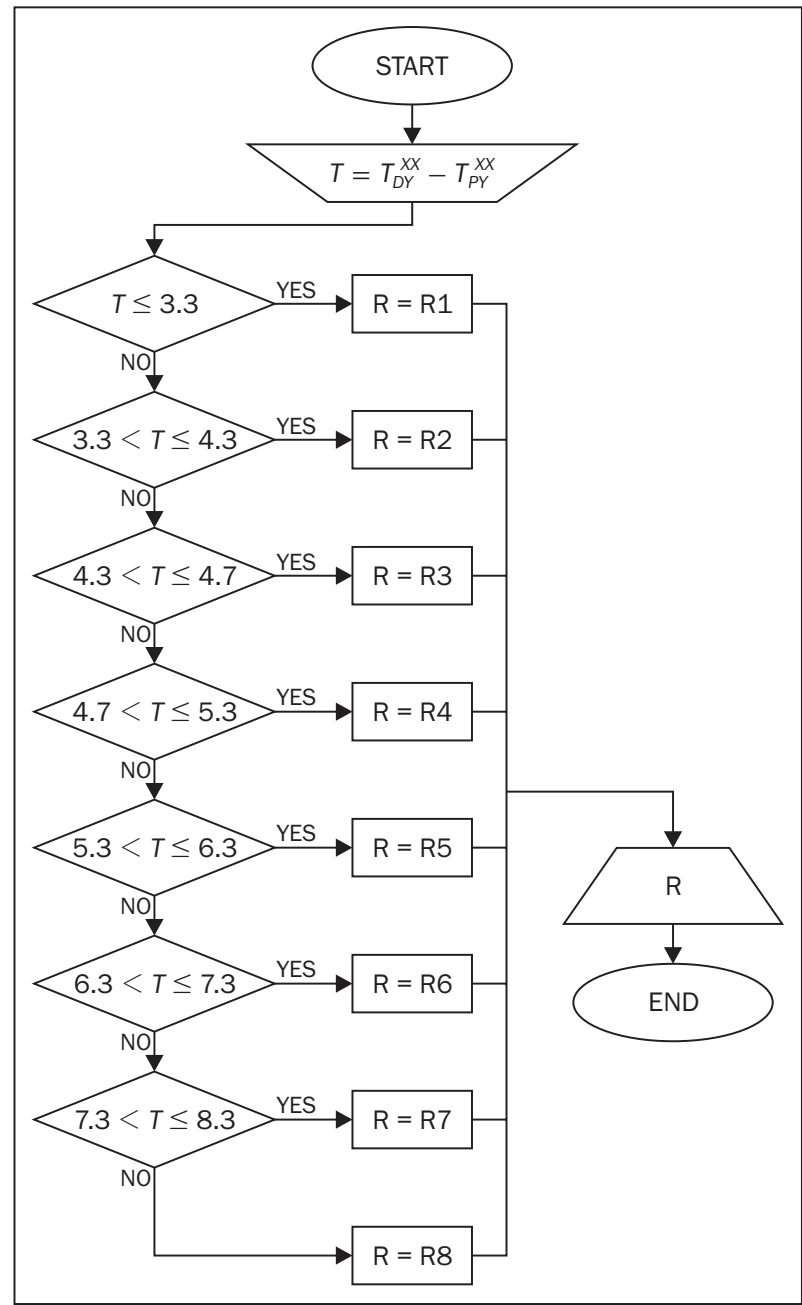

Figure 7 - Flowchart for the selection of the optimal running regime

peak loads, i.e. at high level of usage of the railway line capacity. It is precisely for this reason important, in case of such deviations, to react on time and to start the procedure of timetable adjustment to the real condition in traffic. Such adjustment means the possibility of changing the driving method of the delayed, and if necessary, other trains whose driving depends directly 
or indirectly on the ride of the delayed train. It is necessary here to adjust their travel times and the times of stay at the stops in order to compensate the current delays and to continue to operate in the way planned by the valid timetable. Therefore, it is important to include sufficient time additions in the form of regular recovery time to pure train running times and buffer time additions for their headway intervals.

In this way higher robustness of the timetable can be achieved, that is, the possibility of its adjustment in order to annul the impact of unpredictable factors that may cause deviation during its implementation.

\section{Dr. Sc. ZDRAVKO TOŠ}

E-mail: zdravko.tos@fpz.hr

Dr. Sc. TOMISLAV JOSIP MLINARIĆ

E-mail: mlinaric@fpz.hr

Dr. SC. HRVOJE HARAMINA

E-mail: hrvoje.haramina@fpz.hr

Sveučilište u Zagrebu, Fakultet prometnih znanosti

Vukelićeva 4, 10000 Zagreb, Hrvatska

\section{SAŽETAK}

\section{UPRAVLJANJE ŽELJEZNIČKIM GRADSKO- PRIGRADSKIM PROMETOM TEMELJENO NA PRIMJENI DINAMIČKOG VOZNOG REDA}

Povećanje potražnje za uslugom prijevoza u željezničkom prigradskom prometu uvjetuje veći stupanj iskorištenja propusne i prijevozne sposobnosti pruga. Pri takvom načinu odvijanja prometa i manja odstupanja od planiranog voznog reda mogu negativno utjecati na njegovu stabilnost, a to može rezultirati i značajnijim smanjenjem kvalitete prijevozne usluge. U okviru ovog istraživanja definiran je model upravljanja željezničkim gradsko-prigradskim prometom uz primjenu dinamičkog voznog reda. On podrazumijeva primjenu sustava podrške pri odlučivanju tijekom postupka prilagodbe voznog reda stvarnom stanju u prometu u obliku genetskog algoritma definiranog na temelju važećih pravila za regulaciju željezničkog prometa i vođenje vlakova. Uz to, ovaj model u svim prigradskim vlakovima podrazumijeva postojanje ekspertnog sustava za određivanje najpogodnijeg režima njihova kretanja s ciljem uštede u potrošnji njihove pogonske energije. U radu je dokazano da se primjenom predloženog modela može unaprijediti željeznički gradskoprigradski promet u pogledu povećanja stabilnosti voznog reda i uštede energije za pogon prigradskih vlakova.

\section{KLUUČNE RIJEČI}

upravljanje željezničkim prometom, genetski algoritam, prilagodba voznog reda, energetski učinkovita vožnja vlaka

\section{LITERATURE}

[1] Mlinarić, T.J., Pirnar, M.: Optimizing Track Infrastructure Availability, Promet Traffic \&Transportation, Vol. 21, 2, Zagreb, 2009, pp. 113-121

[2] Mlinarić, T.J., Nikšić, M., Brkić, M.: Implementation of Fleet Management in Train Traction, Promet Traffic \&Transportation, Vol. 20, 3, Zagreb, 2008, pp. 169180

[3] Mazzarello, M., Ottaviani, E.: A traffic management system for real-time traffic optimisation in railways, Transportation Research Part B: Methodological, Volume 41, Issue 2, February 2007, pp. 246 - 274

[4] Törnquist, J.: Computer-based decision support for railway traffic scheduling and dispatching: $A$ review of models and algorithms, Proceedings of ATMOS. 2005

[5] Wegele, S., Schnieder, E.: Dispatching of train operations using genetic algorithms, Proceedings of the $9^{\text {th }}$ International Conference on Computer-Aided Scheduling of Public Transport (CASPT), San Diego, USA (2004)

[6] Higgins, A., Kozan, E., Ferreira, L.: Heuristic techniques for single line train scheduling, Journal of heuristics, (1997), (3), pp.43 - 62

[7] Buchmueller, S., Weidmann, U., Nash, A.: Development of a dwell time calculation model for timetable planning, Computers in Railways XI, WitPress (2008), pp. $525-534$

[8] Haramina, H.: Improvement of suburban Railway Traffic by Application of the Anticipated Management System Model, Ph.D. Thesis, Zagreb, 2010.

[9] http://www.mathworks.com/help/toolbox/fuzzy/fp61. $\mathrm{html}$ (23.03.2010.)

[10] Hansen, I.A., Pachl, J.: Railway Timetable \& Traffic, Eurailpress, Hamburg, 2008 